\title{
Ram seminal plasma and its functional proteomic assessment
}

\author{
T Leahy ${ }^{1}$, J P Rickard ${ }^{1}$, N C Bernecic ${ }^{1}$, X Druart $^{2}$ and S P de Graaf ${ }^{1}$ \\ ${ }^{1}$ The University of Sydney, Faculty of Science, School of Life and Environmental Sciences, New South Wales, \\ Australia and ${ }^{2}$ Physiologie de la Reproduction et du Comportement, INRA, CNRS, IFCE, Université de Tours, \\ Nouzilly, France
}

Correspondence should be addressed to S P de Graaf; Email: simon.degraaf@sydney.edu.au

\begin{abstract}
Ejaculation results in the confluence of epididymal spermatozoa with secretions of the accessory sex glands. This interaction is not a prerequisite for fertilisation success, but seminal factors do play a crucial role in prolonging the survival of spermatozoa both in vitro and in vivo by affording protection from handling induced stress and some selective mechanisms of the female reproductive tract. Reproductive biologists have long sought to identify specific factors in seminal plasma that influence sperm function and fertility in these contexts. Many seminal plasma proteins have been identified as diagnostic predictors of sperm function and have been isolated and applied in vitro to prevent sperm damage associated with the application of artificial reproductive technologies. Proteomic assessment of the spermatozoon, and its surroundings, has provided considerable advances towards these goals and allowed for greater understanding of their physiological function. In this review, the importance of seminal plasma will be examined through a proteomic lens to provide comprehensive analysis of the ram seminal proteome and detail the use of proteomic studies that correlate seminal plasma proteins with ram sperm function and preservation ability.

Reproduction (2019) 157 R243-R256
\end{abstract}

\section{The importance of extracellular proteins to sperm form and function}

Understanding the influence of exogenous factors in the spermatozoon's environment has been of great interest because sperm development and survival is heavily regulated by its external environment. Most cells develop and survive a changing environment through intracellular and extracellular signals that drive gene expression and the production of new proteins (Davies 2016). For example, heat stress may induce the expression of heat shock proteins that help to refold proteins damaged by an increase in temperature. Spermatozoa are unique in this regard because they are rendered transcriptionally and translationally silent well before they become temporally or spatially competent to fertilise. The final post-meiotic phases of spermatogenesis involve DNA compaction and the removal of ribosomes. These processes seizes gene expression before spermatozoa are released from their nursing Sertoli cell in the seminiferous tubules in the testis (Baker 2011). These testicular spermatozoa are not yet mobile or capable of traversing the female tract and fertilising the oocyte. Therefore, sperm maturation in the male (epididymal maturation) and female tract (capacitation in the oviduct), and the sperm cell's response to in vitro handling stressors and physiological stressors transiting the female tract, is mediated without the involvement of sperm gene expression. Sperm adaptation, maturation and survival are entirely reliant on extrinsic factors surrounding the spermatozoa during transit through the epididymis, at ejaculation and upon entry and passage through the female tract.

Ejaculation results in the confluence of spermatozoa, which are in a mixture of testicular and epididymal fluids, with secretions from the seminal vesicles, prostate and bulbourethral glands (collectively termed the accessory sex glands). This complex fluid remodels the sperm surface and modifies the physiological response of spermatozoa in vitro, during processing associated with assisted reproductive technologies, and upon entering the female genital tract. For this reason, understanding the intricate influence of seminal plasma proteins on sperm cell physiology and their role in guiding the spermatozoa during their the travel from the male to the female tract has been a key focus of reproductive scientists.

\section{The physiological function of seminal plasma}

The secretions of the epididymides and accessory sex glands modulate the function of spermatozoa and the female tract through the provision of signalling factors and glycoproteins with sperm-binding properties. The physiological importance of seminal plasma has been questioned (Bedford 2015) because epididymal 
spermatozoa, which have not been exposed to seminal factors, are capable of fertilisation both in vitro and in vivo (Davis et al. 1991, Rickard et al. 2014). However, sperm survival and fertilising potential is hampered if they are not exposed to seminal factors, and these effects are particularly noticeable if epididymal spermatozoa is deposited in the lower reproductive tract and has to migrate to the site of fertilisation. Reduced fertility has been noted in mice (Pang et al. 1979, Peitz 1988), rats (Queen et al. 1981) and sheep (Rickard et al. 2014) under such conditions and the mouse seminal vesicle protein SVS2 is required for sperm survival in the uterus (Kawano et al. 2014). The prolonged survival and fertility afforded by seminal factors is a combination of its ability to stimulate motility (Maxwell et al. 2007), regulate capacitation (Manjunath et al. 2008, Muino-Blanco et al. 2008), influence sperm storage in the female tract (Manjunath et al. 2007, Talevi \& Gualtieri 2010) and modulate the female immune system to tolerate spermatozoa and the conceptus (Robertson 2007).

Pronounced variability in seminal plasma composition across species has made it difficult to attribute clear physiological effects to the fluid as a whole and to delineate the individual importance of seminal proteins to sperm function and fertility. Variations in the amount and relative contribution of individual accessory sex glands result in dramatic physical and biochemical differences in seminal plasma between eutherian species. For example, it alters whether the ejaculate is expelled in fractions (e.g. dog, boar, stallion) or as one phase (e.g. human, ram, bull) and if these secretions exhibit a gel (human, alpaca) or fluid form (ram, bull). Accessory sex gland secretions also dictate ejaculate volume, which varies according to the site of semen deposition. Ejaculates which are deposited in the vagina are low (bull, ram) in volume and high in concentration to prevent semen backflow. Uterine depositors (boar, stallion) exhibit larger ejaculate volumes with lower sperm concentration. These adaptions of the accessory sex glands to suit evolutionary divergent mating strategies result in pronounced proteome diversity of seminal fluid between species (Druart et al. 2013, Meslin et al. 2015). Even major protein families which are highly conserved across ungulates (i.e., pig, bull, ram, stallion), such as spermadhesins and binder of sperm proteins (BSP), appear to function in a species-specific manner. Differences in the structure, abundance and expression patterns of homologous proteins may underlie the functional divergences that are evident in even closely related species such as the bull and the ram (Leahy \& de Graaf 2012). Due to these inherent variabilities, we have narrowed the focus of this review to allow for a comprehensive proteomic assessment of the effect of seminal plasma proteins from that of a single species, the ram.

\section{The use of seminal plasma to improve ram sperm function during processing for artificial reproductive technologies}

A goal of animal reproductive biologists has been to ascertain what the physiological functions of seminal plasma are and examine if this complex fluid could be used as a biotechnological tool to improve sperm function during processing for artificial reproductive technologies (ARTs). In vitro processing of spermatozoa for liquid storage, cryopreservation or sex sorting dramatically alters the extracellular fluid environment of the sperm sample. The most obvious effect is a dramatic dilution of seminal plasma proteins in the sperm environment from extension with diluents optimised for reproductive technologies. Wherever possible, in vitro handling attempts to mimic the signals and protective aspects of the in vivo environment to maintain sperm form and function. Semen processing also results in fluctuations of temperature, pressure, osmolality and $\mathrm{pH}$ that can damage the sperm plasma membrane and limit the fertilising lifespan of processed spermatozoa. These in vitro changes share many similarities to in vivo capacitation, such as alterations in lipid packing, cholesterol efflux and tyrosine phosphorylation. Because they occur in vitro, prior to deposition in the female tract, rather than at the site of in vivo fertilisation (the oviduct), the fertilising window of processed spermatozoa is considerably shortened (Bailey et al. 2000). As seminal plasma is removed or diluted during processing, and it contains factors which prevent premature capacitation (Chang 1957, Tseng et al. 2013), it has long been viewed as a physiological fluid that could protect spermatozoa from handling-induced stress.

Indeed, the vast majority of studies investigating the influence of ram seminal plasma on ram sperm function report improved sperm parameters (MuinoBlanco et al. 2008, Leahy \& Gadella 2011, Leahy \& de Graaf 2012) and this has translated to improved in vivo fertility (Maxwell et al. 1999b, Rickard et al. 2014). The inclusion of ram seminal plasma into sperm-handling protocols has been shown to have a decapacitation effect on frozen-thawed ram spermatozoa (assessed by an increased proportion of non-capacitated spermatozoa following chlortetracycline staining) and improve a range of other sperm quality characteristics including sperm heterogeneity, viability, motility and ability to penetrate cervical mucus in vitro (Graham 1994, Garcia-Lopez et al. 1996, Maxwell et al. 1999a, Barrios et al. 2000, Perez-Pe et al. 2001a, 2002, El-Hajj Ghaoui et al. 2007a,b, Leahy et al. 2009, 2010c). Glycoproteins in seminal plasma have been proposed to bind to the sperm membrane and have a stabilising effect on the membrane structure, as it adapts to changes in the temperature gradients during freezing and thawing 
(Muino-Blanco et al. 2008). In part, this positive effect on sperm functioning is also due to anti-oxidant effects elicited by seminal plasma (Marti et al. 2007). In line with this, the addition of seminal plasma proteins has also been shown to protect sex-sorted ram spermatozoa from oxidative stress (Leahy et al. 2010a).

As seminal plasma is a complex biological fluid, intra-species variation in its effect on spermatozoa has also been reported. Extracellular interactions of spermatozoa and seminal plasma vary at the animal level due to physiological, pathological and exogenous (e.g. hormones, disease, season) factors (Maxwell et al. 2007, Muino-Blanco et al. 2008, Leahy et al. 2010c, Rickard et al. 2016). In vitro processing of spermatozoa and seminal plasma further influences the final outcome with noted differences in effect of seminal plasma due to the washing of spermatozoa (Ollero et al. 1997, Perez-Pe et al. 2001b), the point at which seminal plasma is introduced, and the protein concentration applied (Leahy et al. 2009). Such variability is thought to account for studies which find no influence of seminal plasma on ram sperm survival (Morrier et al. 2003) or a detrimental effect (Dott et al. 1979, de Graaf et al. 2007). Such inherent variability also contributes to the inconsistent effect of seminal plasma supplementation on the in vivo fertility of liquid-stored and frozen-thawed ram spermatozoa (Maxwell et al. 1999b, El-Hajj Ghaoui et al. 2007b, O'Meara et al. 2007, Leahy et al. 2010b, López-Pérez \& Pérez-Clariget 2012, Rickard et al. 2014). To better delineate the seminal factors influencing sperm function, andrologists have utilised the latest advances in mass spectrometry (MS) technology to identify and quantify the entire protein complement (proteome) of seminal plasma and correlate protein abundance to ram sperm preservation ability.

\section{From seminal proteins to the ram seminal proteome}

Identification of the protein makeup of ram seminal plasma was initially performed by selecting bands or spots of interest from 1 or 2D SDS-PAGE and performing mass spectrometry (MS) on these targeted areas of interest.
Such techniques identified the highly abundant, lowmolecular-weight $(14-30 \mathrm{kDa})$ proteins in ram seminal plasma as members of the spermadhesin and binder of sperm protein (BSP) families (Bergeron et al. 2005, Cardozo et al. 2008). Over the next decade, the rapid development of mass spectrometry technology allowed for the global identification and quantification of proteins in complex biological fluids and tissues to identify close to the entire protein complement of a sample. These technological advances were enthusiastically adopted in the reproductive community and led to a rapid increase in the number of proteins identified in reproductive tissues, fluids and cells. Seminal plasma proteomes have now been reported in most species including, the boar (González-Cadavid et al. 2014, Perez-Patino et al. 2016, Pérez-Patiño et al. 2018), turkey (Slowinska et al. 2017), stallion (Novak et al. 2010) and bull (Kelly et al. 2006, Viana et al. 2018) as well as humans and other nonmammalian species (reviewed by Druart \& de Graaf 2018). Dramatic increases in the identification of ram seminal plasma proteins were evidenced over sequential years from 61 in 2012 (Souza et al. 2012) to 109 in 2013 (Druart et al. 2013) and 727 protein identifications the following year (Soleilhavoup et al. 2014). The rapid increase in the number of seminal plasma proteins identified was largely due to improvements in mass spectrometry technology, particularly in the initial separation of peptides in the liquid chromatography phase prior to mass characterisation (Byrne et al. 2012).

Characterisation of the global seminal plasma proteome allowed for the system-wide modelling of this complex biological fluid to better understand biological clusters within seminal plasma, and potential interactions between seminal plasma and ram spermatozoa (Soleilhavoup et al. 2014). Relative protein quantification by spectral analysis revealed the protein composition of ram seminal plasma was highly unbalanced, as $5 \%$ of the proteins (39 out of 727 proteins) constituted $50 \%$ of the total spectra (top 10 most abundant proteins shown in Table 1) (Soleilhavoup et al. 2014). The proteins of high abundance included previously identified seminal proteins such as BSP proteins (BSP5) (Cardozo et al. 2008)

Table 1 The major proteins identified in ram seminal plasma after LC-MS/MS, based on total spectra counts (Soleilhavoup et al. 2014).

\begin{tabular}{|c|c|c|c|}
\hline Protein name & Gene symbol & $\mathbf{M W}(\mathrm{kDa})$ & Function \\
\hline Binder of sperm 5 precursor & BSP5 & 17.8 & $\begin{array}{l}\text { Binder of sperm (BSP) glycoprotein characterised by a } \\
\text { fibronectin type-2 domain. Binds sperm }\end{array}$ \\
\hline UPF0762 protein C6orf58 & LEG 1 & 40.9 & Protein of unknown function \\
\hline Clusterin & $C L U$ & 51.0 & $\begin{array}{l}\text { Ubiquitous glycoprotein with chaperone and } \\
\text { anti-apoptotic functions }\end{array}$ \\
\hline Bodhesin-2 & $\mathrm{BDH} 2$ & 11.7 & $\begin{array}{l}\text { Spermadhesin protein characterised by a CUB domain. } \\
\text { Binds sperm }\end{array}$ \\
\hline Alpha-2-macroglobulin & $A 2 \mathrm{M}$ & 164.2 & Protease inhibitor \\
\hline Carboxylesterase $5 \mathrm{~A}$ & CES5A & 64.2 & Enzyme involved with lipid transfer processes \\
\hline Lactoferrin & LTF & 77.2 & $\begin{array}{l}\text { Antimicrobial activity and serine-type endopeptidase } \\
\text { activity. Iron binding }\end{array}$ \\
\hline $\begin{array}{l}\text { EGF-like repeat and discoidin I-like domain-containing } \\
\text { protein } 3\end{array}$ & EDIL3 & 54.9 & $\begin{array}{l}\text { Cell adhesion ligand that interacts with the } \\
\text { alpha-v/beta-3 integrin receptor. Calcium binding }\end{array}$ \\
\hline
\end{tabular}


and spermadhesins (BDH-2) (Bergeron et al. 2005) as well as common serum proteins (albumin, clusterin, lactoferrin). A more unexpected finding was that the second most abundant seminal plasma proteins identified by spectral counting had not previously been reported in ram seminal plasma, nor in the seminal plasma of any mammalian species. Liver-enriched gene 1 (LEG1, also known as UPF0762 or c6orf58 protein) is a glycosylated, secretory protein, which contains a domain of unknown function (DUF781) (Chang et al. 2011). In the zebrafish, LEG1 has been shown to protect liver development from oxidative stress by mediating a novel anti-stress pathway that involves FGFR3 binding and the enhancement of Erk activity (Lin et al. 2014, Hu et al. 2016).

The function of LEG1 in the reproductive context is unknown, but it has been identified in the proteome of ejaculated ram spermatozoa, and not epididymal ram spermatozoa, suggesting that this protein is secreted by an accessory male sex gland and is mixed with epididymal sperm at ejaculation (Pini et al. 2016). The protein is abundantly present in seminal plasma (Soleilhavoup et al. 2014) but only low amounts of this protein were found to be interacting with the ram sperm membrane (Pini et al. 2016). Interestingly, out of the 700 plus proteins identified in seminal plasma, LEG1 was only one of three proteins that were present on ejaculated spermatozoa and absent on epididymal spermatozoa (Pini et al. 2016). The other two proteins were BSP5 and a cell adhesion protein termed EGFlike repeat and discoidin I-like domain-containing protein 3 (EDIL3). The interaction of BSP5 with the sperm membrane has been well documented and shown to occur in a rapid and specific manner through interactions with choline phospholipids (Desnoyers \& Manjunath 1992). The association of EDIL3 with the sperm membrane has not been directly studied but EDIL3 is an integrin ligand, which binds the alpha-v/ beta-3 integrin receptor, suggesting a possible target for sperm-bound EDIL3. In endothelial cells, EDIL3 has interesting properties of immune evasion and manipulation, by limiting leukocyte recruitment during inflammation (Choi et al. 2008). This interesting immune modulatory function may assist spermatozoa in evading the female immune system. Collectively, these results show that the confluence of spermatozoa with seminal plasma at ejaculation re-models the ram sperm plasma membrane in a highly specific way, but this does not occur through the addition of a significant number of new proteins. Suggesting that the proteomic interaction of spermatozoa and its seminal environment is perhaps not as complex as previously thought. The relevance of the binding of EDIL-3 to integrin receptors on the sperm surface for sperm survival in the female tract remains to be determined in future studies.
Further functional enrichment assessments of the proteomic datasets revealed that the global ram SP proteome contained proteins involved in three main protein pathways; proteins involved in metabolism (predominantly glycolytic enzymes), the ubiquination pathway (heat shock proteins, 26s proteasome proteins and ubiquination proteins) and chaperone-related proteins (heat shock proteins, proteins of the chaperonincontaining TCP1 complex). These pathways are typically cellular in origin and are the predominate functional pathways of mammalian spermatozoa (Baker et al. 2008, Byrne et al. 2012, Nixon et al. 2017). The arrest of spermatogenesis by scrotal insulation caused the loss of these proteins from seminal plasma, confirming that there are a high number of proteins in ram seminal plasma that are of sperm origin (Soleilhavoup et al. 2014).

\section{The correlation of protein quantity to biological function}

Advances in the qualitative and quantitative power of mass spectrometry technology allowed for variations in sperm preservation ability to be correlated to the relative amount of seminal plasma proteins. The balance of this review article provides an in-depth assessment of three quantitative proteomic studies that correlate the relative quantities of ram seminal plasma proteins to ram sperm function at ejaculation (Rodrigues et al. 2013), after liquid storage for $24 \mathrm{~h}$ at $15^{\circ} \mathrm{C}$ (Soleilhavoup et al. 2014) and after freezing and thawing (Rickard et al. 2015). Proteins that were statistically more abundant in the seminal plasma of animals which displayed high or low motility in vitro is shown in Fig. 1. Liquid chromatography MS/MS and spectral counting was used for the assessment of seminal proteins related to sperm function following liquid or frozen storage. This technique allowed for the quantification of all proteins in the sample and their statistical correlation with either high or low preservation ability. The study correlating seminal proteins to sperm motility patterns at ejaculation used densitometry of spots on a $2 \mathrm{D}$ gel to identify potential proteins overexpressed in high- or low-motility samples. These spots were then isolated and identified by mass spectrometry. Accordingly, this technique resulted in a reduced number of proteins $(n=4)$ being correlated to sperm function compared to the proteomic studies which identified all the complete seminal plasma proteome (Fig. 1).

The purpose of the detailed assessment of these three studies is to better understand the biological function of ram seminal plasma and to identify the common and divergent responses of seminal proteins under varied handling conditions. One of the key benefits of proteomics is that it allows you to take a systems biology, 


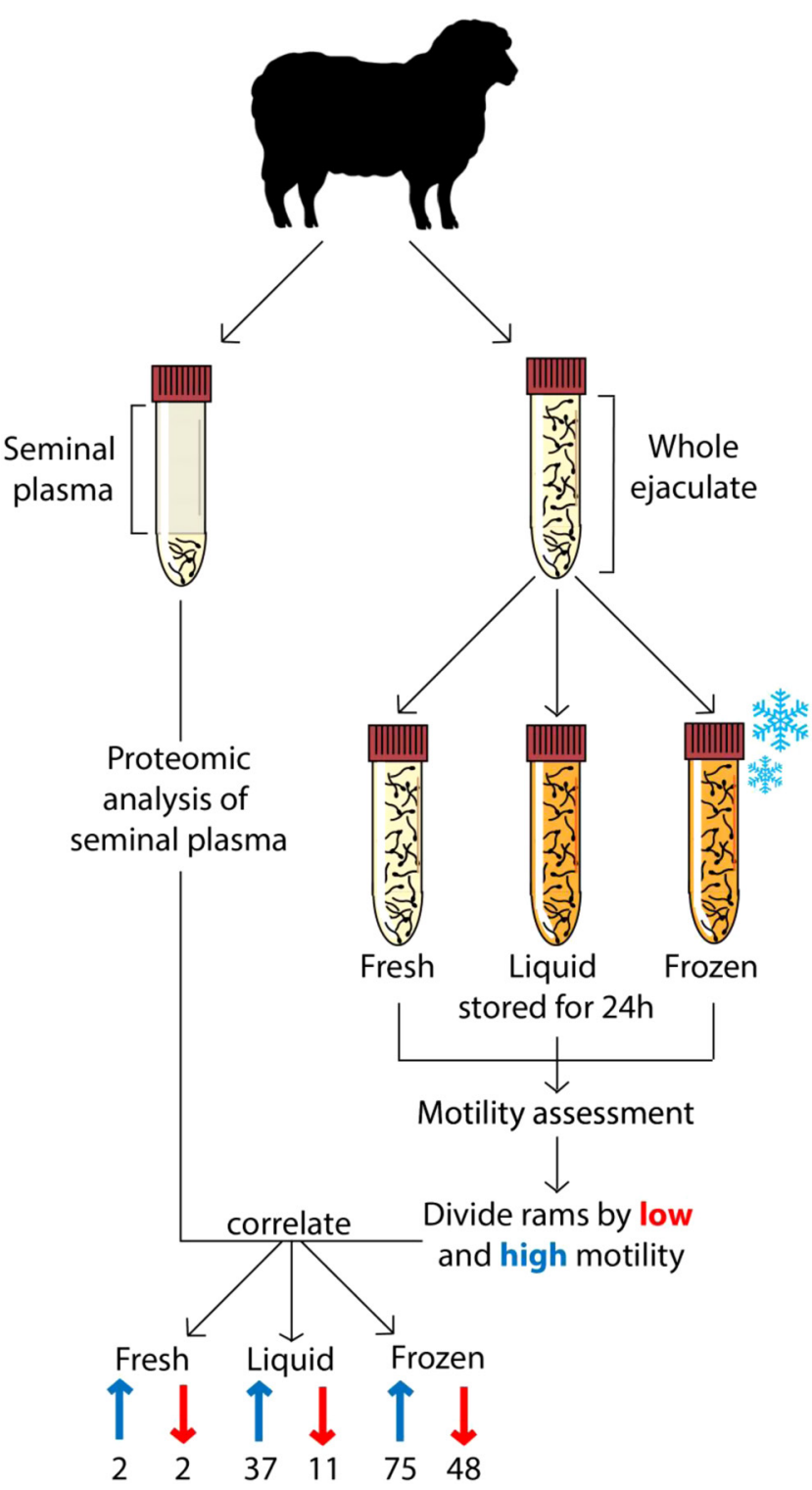

Figure 1 Proteomic studies correlating protein quantification to ram spermatozoa function in vitro. Seminal plasma proteins were separated by 2D SDS-PAGE and densitometry and mass spectrometry was used to quantify and identify, respectively, protein abundance. Seminal plasma proteins were identified and quantified by LC-MS/MS and spectral counting. Proteins that were statistically overexpressed in sperm samples showing high (blue arrow) or low (red arrow) motility at ejaculation (Rodrigues et al. 2013), following $24 \mathrm{~h}$ of liquid storage (Soleilhavoup et al. 2014) or after freeze-thawing (Rickard et al. 2015) are shown.

or holistic, approach to complex biological traits. For example, rather than identifying individual proteins that are correlated to fertility, you can assess which biological networks may influence sperm function or fertility. Global assessment of these three comparative proteomic investigations (fresh, liquid, frozen) identified five key proteins groupings that were positively or negatively associated with sperm preservation ability and these will be discussed below.

\section{Secreted or extracellular proteins correlated with ram sperm function in vitro}

Many of the abundant proteins that are known to be secreted from the accessory sex glands were negatively correlated to sperm function or preservation ability in the comparative proteomic studies (Table 2). This finding was somewhat surprising as many of these 'classical' seminal plasma proteins have been shown to have beneficial effects on ram sperm function when added in isolation in functional in vitro studies (MuinoBlanco et al. 2008). One of the most abundant, and well-characterised proteins in ram seminal plasma (BSP5), which belongs to the binder of sperm protein (BSP) family, was significantly correlated with lower ram spermatozoa motility following ejaculation (Rodrigues et al. 2013) (Table 2), whereas BSP1 and five showed no correlation to sperm survival following liquid or frozen storage. Such a result is unexpected, as BSP proteins isolated from ram seminal plasma have been shown to be beneficial to ram sperm survival in vitro, particularly following freezing and thawing. Binder of sperm proteins are small acidic proteins which originate in the seminal vesicles and are designated by the presence of two tandemly repeated fibronectin type 2 (Fn-2) modules. Ejaculation causes rapid and specific binding to the ram sperm membrane (Pini et al. 2016) through the direct association of BSP proteins with choline phospholipids (Manjunath et al. 2007). This association is thought to restrict the mobility of the lipid phase and result in a rigidification of the sperm membrane that provides stability during sperm transit through the reproductive tract (Manjunath et al. 2007). In the ram, this effect was attributed to the improved sperm viability and reduced tyrosine phosphorylation noted in spermatozoa supplemented with BSP proteins before exposure to cold shock conditions (Perez-Pe et al. 2001a, 2002) or in standard ram freezing protocols (Pini et al. 2018a). Upon reaching the oviduct, BSP proteins may also assist in the establishment of a bovine oviductal sperm reservoir as in vitro supplementation of BSP proteins to epididymal spermatozoa enhances sperm-oviductal epithelial cell binding (Gwathmey et al. 2003, 2006). It is proposed that when the oocyte arrives, secondary messengers in the oviductal fluid, such as high-density lipoprotein and heparin-like glycosaminoglycan's may bind to BSP proteins to coordinate the onset and progression of capacitation (Lane et al. 1999). In the bull, extended association of BSP proteins with spermatozoa in vitro has been well documented to cause capacitation-like changes, such as cholesterol efflux, which result in a loss of sperm viability (Manjunath et al. 2007) but such a pronounced effect has not been observed in the ram. This result highlights an important consideration of in vitro sperm storage. That while it may dilute seminal factors, it also significantly extends the amount of time spermatozoa associate with such proteins from a few minutes, at most, following ejaculation and deposition 
Table 2 Secretory or extracellular-localised proteins that are statistically more abundant in ram sperm samples shower higher ( $\uparrow$ ) or lower $(\downarrow)$ motility following ejaculation (fresh (Rodrigues et al. 2013)), or after liquid (Soleilhavoup et al. 2014) or frozen storage (Rickard et al. 2015).

\begin{tabular}{|c|c|c|c|c|}
\hline Protein name & Gene name & Fresh & Liquid & Frozen \\
\hline Disintegrin and metalloproteinase domain protein 20 & ADAM20 & & & $\downarrow$ \\
\hline Disintegrin and metalloproteinase domain protein 32 & ADAM32 & & & $\downarrow$ \\
\hline Cartilage acidic protein 1 & CRTAC1 & & $\downarrow$ & $\downarrow$ \\
\hline Extracellular matrix protein 1 isoform 1 & ECM1 & & $\downarrow$ & $\downarrow$ \\
\hline Binder of sperm 5 & BSP5 & $\downarrow$ & & \\
\hline Bodhesin 2 & $\mathrm{BDH} 2$ & $\downarrow$ & & \\
\hline Angiogenin-2-like & ANG & & & $\downarrow$ \\
\hline UPF0762 protein C6orf58 homolog & LEG 1 & & $\downarrow$ & \\
\hline Ribonuclease 4 isoform 1 & RNASE4 & & $\uparrow$ & $\downarrow$ \\
\hline Zinc-alpha-2-glycoprotein-like & $A Z G P 1$ & $\uparrow$ & $\downarrow$ & $\downarrow$ \\
\hline EGF-containing fibulin-like extracellular matrix 1 & EFEMP1 & & $\uparrow$ & $\uparrow$ \\
\hline Caltrin-like & PYY2 & & & $\uparrow$ \\
\hline
\end{tabular}

in the female tract to days, months or years when spermatozoa are processed and stored in a liquid or frozen form. In the bull, it is thought that this extended association of BSP proteins with spermatozoa disrupts the natural balance of inhibition and stimulation of capacitation and leads to a loss of sperm function and fertility (Manjunath et al. 2008, Leahy \& Gadella 2011). Accordingly, quantitative proteomic studies have associated both high and low levels of BSP proteins with poor fertility outcomes following artificial insemination of frozen-thawed bull spermatozoa (Moura et al. 2006, Somashekar et al. 2015). In the ram, the lack of quantitative association of BSP proteins with sperm preservation ability may relate to their shear abundance in ram seminal plasma masking clear quantitative effects. This, however, does not fully explain why higher levels of BSP5 were correlated to reduced motility at ejaculation (Rodrigues et al. 2013). Nor why many other abundant secreted seminal plasma proteins were also negatively correlated to motility following ejaculation (the spermadhesin $\mathrm{BDH} 2$ ) or liquid storage (LEG1) (Table 2).

Another secretory seminal protein of interest is zinc-alpha-2-glycoprotein-like (AZGP1, ZAG). This protein showed an interesting biphasic effect of being beneficial in the short term but detrimental under longterm preservation conditions (Table 2). As the amount of AZGP1 in ram seminal plasma was positively correlated with ram sperm motility following ejaculation (Rodrigues et al. 2013) but negatively correlated with preservation ability following liquid (Soleilhavoup et al. 2014) or frozen (Rickard et al. 2015) storage. In humans, AZGP1 is secreted by the prostate (Hale et al. 2001) and binds to the surface of spermatozoa at ejaculation where it stimulates sperm motility through the cyclic AMP pathway (Qu et al. 2007). As successful sperm preservation relies on the depression or cessation of sperm movement and metabolic activity, it is clear why a stimulatory factor that aids sperm transit through the female tract would not be beneficial under prolonged in vitro storage conditions. Indeed, when recombinant AZGP1 was tested on ram spermatozoa, a stimulatory effect prior to liquid storage and a detrimental effect after storage was found (Soleilhavoup et al. 2014).

One of the only small, secreted proteins of seminal origin that was positively correlated (Table 2) with improved ram sperm motility following freezing and thawing was caltrin (calcium transport inhibitor; PYY2). Caltrin is secreted by the seminal vesicles (Coronel et al. 1992, Chen et al. 1998) and was one of the first decapacitation factors to be characterised in bovine seminal plasma (Lewis et al. 1985). The serineprotease inhibitor binds to spermatozoa at ejaculation and inhibits extracellular Ca2+ uptake to prevent premature acrosomal exocytosis and hyperactivation as spermatozoa ascend through the female reproductive tract (Dematteis et al. 2008, Grasso \& Coronel 2017). The influence of caltrin on ram spermatozoa has not been investigated in vivo or in vitro but a related serineprotease inhibitor, termed SPINK3, was able to partially prevent or revert ram spermatozoa freeze-thaw damage (Zalazar et al. 2016). Further investigation of the ability of PYY2 to prevent capacitation-like changes caused by freeze-thaw damage is warranted.

Finally, many extracellular matrix proteins (Table 2), of testicular origin, which are involved in cell adhesion (e.g. a disintegrin and metalloprotease proteins; ADAM proteins) were correlated with poor motility following liquid or frozen storage (ADAM20, ADAM32, CRTAC1, ECM1). The exception to this was EGF-containing fibulin-like extracellular matrix 1 (EFEMP1), which was positively correlated with storage resilience in liquid or frozen form.

\section{Immune-related proteins correlated with ram sperm function in vitro}

Several proteins of the humoral (cell-free bodily fluid or serum) immunity system showed both positive and negative correlations with motility following liquid or frozen storage (Table 3). Secreted antimicrobial proteins of the BPI fold-containing family (BPIFA1 and BPIFB1) were negatively correlated to frozen sperm storage, but the concentration of BPIFB1 in seminal plasma was 
Table 3 Immune-related proteins that are statistically more abundant in ram sperm samples shower higher $(\uparrow)$ or lower $(\downarrow)$ motility after liquid (Soleilhavoup et al. 2014) or frozen storage (Rickard et al. 2015).

\begin{tabular}{|c|c|c|c|}
\hline Protein name & Gene name & Liquid & Frozen \\
\hline $\begin{array}{l}\text { BPI fold-containing family A } \\
\text { member } 1\end{array}$ & BPIFA1 & & $\downarrow$ \\
\hline Cystatin C & CST3 & & $\downarrow$ \\
\hline Immunoglobulin alpha heavy chain & IGHA1 & & $\downarrow$ \\
\hline $\begin{array}{l}\text { Polymeric immunoglobulin receptor } \\
\text { isoform } 1\end{array}$ & $P I G R$ & $\downarrow$ & $\downarrow$ \\
\hline C-reactive protein-like & $C R P$ & & $\uparrow$ \\
\hline Cathelicidin-1 precursor & CATHL1B & $\uparrow$ & \\
\hline Immunoglobulin V lambda chain & Vlambda 16.1 & $\uparrow$ & \\
\hline Ig gamma-1 chain $\mathrm{C}$ region, partial & IGHG 1 & $\uparrow$ & \\
\hline Immunoglobulin gamma-1 chain & Ig gamma-1 & $\uparrow$ & \\
\hline $\begin{array}{l}\text { BPI fold-containing family B } \\
\text { member } 1\end{array}$ & BPIFB1 & $\uparrow$ & $\downarrow$ \\
\hline
\end{tabular}

positively correlated to motility following liquid sperm storage. BPI-containing proteins bind lipids, display antibacterial activity against gram-negative bacteria, and are involved in inflammatory responses at the cell surface (Britto \& Cohn 2015). Other antimicrobial proteins (C-reactive protein (CRP)) and peptides (Cathelicidin-1 precursor (CATHL1B)) were also positively correlated with frozen and liquid storage, respectively.

Immunglobulins, or antibodies, of the adaptive immune response were also both positively and negatively associated with sperm function in vitro. For example, immunoglobulin A (IGHA1) and the polymeric immunoglobulin receptor (PIGR) were negatively corrected with sperm preservation ability. Receptor proteins with transmembrane domains, such as PIGR, would not normally be expected in plasma fluids. The PIGR protein is a special case because it binds $\lg A$ at the basolateral surface of epithelial cells and transport the complex to the apical surface for secretion (Johansen \& Kaetzel 2011). Secretion cleaves the extracellular component of the PIGR protein from the transmembrane segment where it can be detected in seminal plasma (Phalipon \& Corthésy 2003, Kaetzel 2005) and provide a quantitative measure of immunoglobulin secretion levels. Other immunoglobulins, IgG (IGHG1 and the Immunoglobulin V lambda chain (Vlambda16.1)), showed the opposite response and were positively correlated with motility following liquid storage. Immunoglobulins (particularly $\lg G$ and $\lg A$ ) and antimicrobial proteins and peptides are part of the normal humoral immunity system present in seminal plasma (Bier et al. 1977, Dondero et al. 1984). The abundance of these immune proteins is clearly correlated to sperm function, but the relationship is unlikely to be a simple linear one. Immune competency at the humoral level relies on having an established baseline of proteins involved in innate (antimicrobial proteins/peptides) and adaptive (immunoglobulins) immunity. Therefore, a depression of immune-related proteins may indicate an immune-compromised state. On the other hand, the secretion of these proteins greatly increases during acute phase response to inflammatory stimuli caused by injury or infection so elevated levels of immune-related proteins may indicate an inflammatory state (Peterson \& Artis 2014). Therefore, the quantitative relationship of immune proteins to sperm function and fertility is likely to be a quadratic one where too little expression or too great expression of immune proteins is associated with poor sperm function.

\section{Chaperone-related proteins correlated with ram sperm function in vitro}

Three functional cell-based pathways were previously reported in the ram seminal proteome (Soleilhavoup et al. 2014). In the comparative proteomic studies, all three of these pathways showed clear correlations with sperm preservation ability (Soleilhavoup et al. 2014, Rickard et al. 2015). The vast majority of the proteins in these functional pathways (Fig. 2) were of sperm origin and their abundance in seminal plasma was predominantly positively associated with sperm preservation ability.

The first of these is proteins with chaperone-like activity, which assist in the folding and unfolding, and the assembly or disassembly, of macromolecular structures. All the chaperone proteins that were associated with preservation ability were positively correlated with high motility following liquid or frozen storage (Fig. 2 and Table 4). The majority of chaperone proteins identified were part of the chaperonin-containing TCP1 complex (CCT complex), which is composed of eight unique subunits that are stacked like two donuts on top of each other to create a barrel. It is thought to primarily fold and stabilise cytoskeletal proteins due to the continuous presence of tubulin and actin in the CCT complex (Sarkar et al. 2011). The CCT complex shows a unique plasma membrane localisation (bull; Byrne et al. 2012, boar; Belleannee et al. 2011, human; Redgrove et al. 2011 and mouse; Dun et al. 2011) in spermatozoa and has been shown to associate with proteins of zona-binding affinity. Subunits of the CCT complex have previously been identified in ram seminal plasma, but they were not detectable following scrotal insulation, indicating they were of sperm origin (Soleilhavoup et al. 2014). It is therefore unlikely that the quantity of these proteins in the extracellular environment is having a direct effect on sperm quality in vitro but their abundance does appear to be a reliable diagnostic marker of sperm quality as all eight CCT subunits showed the same positive trend with perseveration ability. The mechanism by which these cellular proteins enter the extracellular environment is unclear, but it may be caused by cell turnover in the epididymis or ejaculate.

Secretory chaperone proteins, termed heat shock proteins, were also positively associated with sperm 

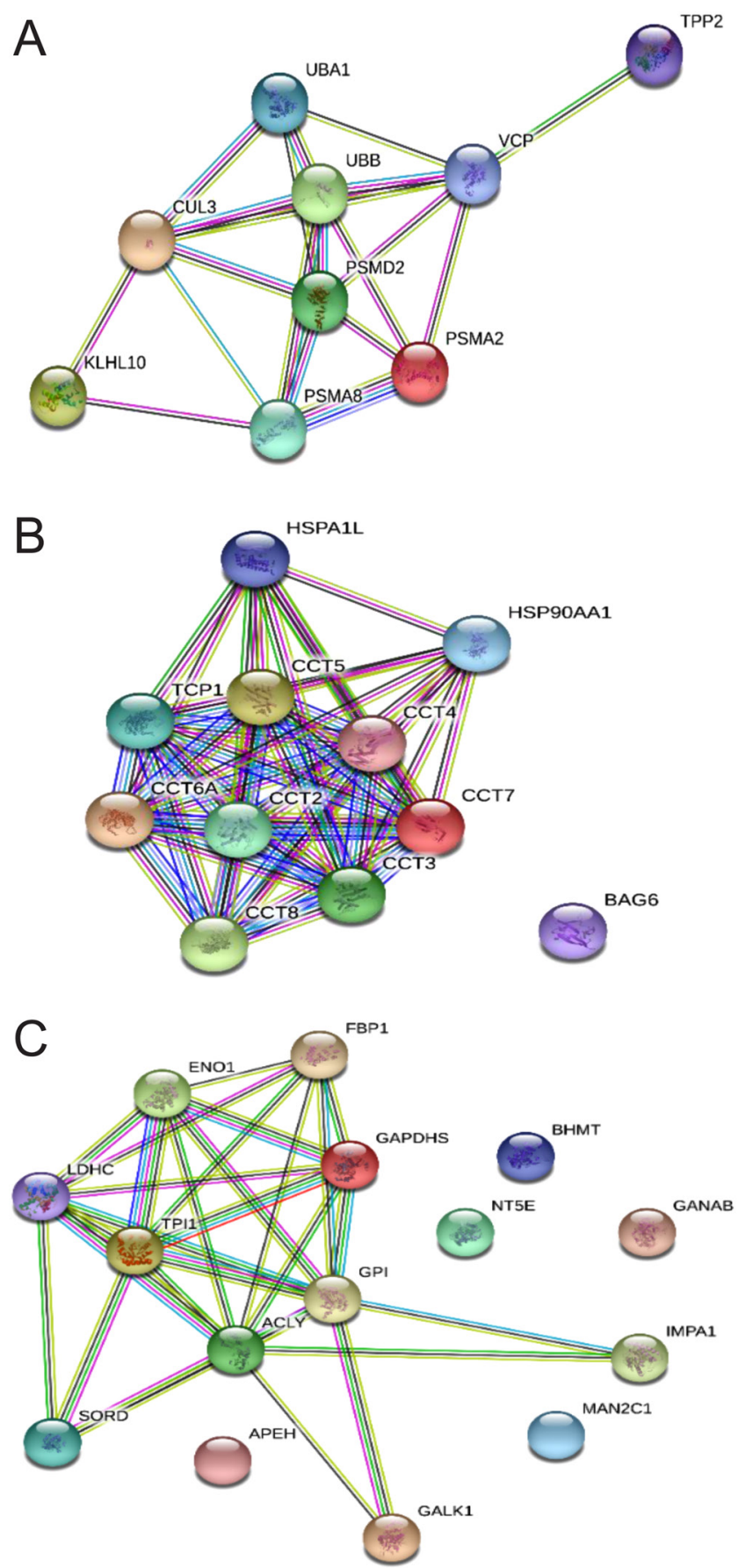

Figure 2 Visualisation of the network of (A) chaperone (Table 4), (B) proteolytic (Table 5) and (C) metabolism-related proteins (Table 6) in ram seminal plasma that are correlated to in vitro sperm function. Protein connections were established using STRING (http:// string-db.org).

survival in vitro (HSPA1L, HSP90AA1). In spermatozoa, chaperone proteins have also been shown to assist in the assembly and delivery of zona-binding proteins to the outer surface of the sperm plasma membrane (Redgrove et al. 2011, Bromfield et al. 2016). Heat shock proteins are ubiquitous proteins that prevent protein aggregation
Table 4 Chaperone-related proteins that are statistically more abundant in ram sperm samples shower higher $(\uparrow)$ or lower $(\downarrow)$ motility after liquid (Soleilhavoup et al. 2014) or frozen storage (Rickard et al. 2015).

\begin{tabular}{llcc}
\hline Protein name & Gene name & Liquid & Frozen \\
\hline Large proline-rich protein BAG6 & BAG6 & & $\uparrow$ \\
T-complex protein 1 subunit alpha & CCT1 & $\uparrow$ \\
T-complex protein 1 subunit beta & CCT2 & $\uparrow$ \\
T-complex protein 1 subunit gamma & CCT3 & & $\uparrow$ \\
T-complex protein 1 subunit delta & CCT4 & $\uparrow$ \\
T-complex protein 1 subunit theta & CCT8 & & $\uparrow$ \\
Heat shock 70 kDa protein 1-like & HSPA1L & $\uparrow$ & $\uparrow$ \\
T-complex protein 1 subunit epsilon & CCT5 & $\uparrow$ & $\uparrow$ \\
T-complex protein 1 subunit zeta & CCT6A & $\uparrow$ & $\uparrow$ \\
T-complex protein 1 subunit eta & CCT7 & $\uparrow$ & $\uparrow$ \\
Heat shock protein HSP 90-alpha & HSP90AA1 & $\uparrow$ & $\uparrow$ \\
\hline
\end{tabular}

and may be induced by stress, constitutively expressed or both (Rupik et al. 2011). Increased HSPs could therefore be a marker of physiological stressors in the male tract or they could indicate a high-functioning chaperone system, which may afford protection from stressors associated with in vitro handling and aid sperm-zona binding. In this case, the latter appears to be more correct as these markers were positively associated with sperm preservation ability (Table 4). Moreover, multiple HSP proteins were more abundant in the seminal plasma of men with high seminal reactive oxygen species levels but the two proteins more abundant in the medium and low ROS groups (HSPA1L and HSP90AA1, respectively, Agarwal et al. 2015) were the same HSP proteins correlated with ram sperm preservation ability. Higher abundance of the HSP90AA1 protein in the spermatozoa of good freezer boars has also been reported in the boar (Casas et al. 2010) and chaperone proteins have been identified as the functional group most susceptible to freeze-thaw damage as there abundance in ram spermatozoa is greatly reduced following freeze-thawing (Pini et al. 2018b). This makes HSPs good candidates for future research into bioactive cryoprotectants. Recombinant HSPA8 proteins has been shown to prolong ram sperm survival in vitro at $39^{\circ} \mathrm{C}$ (Lloyd et al. 2009) and further testing of HSP90AA1 supplementation during liquid or frozen storage is warranted.

\section{Proteolysis-related proteins correlated with ram sperm function in vitro}

All of the proteins involved in proteolysis through the multi-catalytic cellular complex known as the Ubiquitin Proteasome System (UPS) were positively correlated with motility following liquid or frozen storage (Fig. 2 and Table 5). The UPS system targets proteins for destruction by tagging them with a ubiquitin chain to direct them to the 26S proteasome complex for destruction. When proteasomal activity was first identified in spermatozoa, it was expected to coordinate the intracellular 
Table 5 Proteolysis-related proteins that are statistically more abundant in ram sperm samples shower higher $(\uparrow)$ or lower $(\downarrow)$ motility after liquid (Soleilhavoup et al. 2014) or frozen storage (Rickard et al. 2015).

\begin{tabular}{|c|c|c|c|}
\hline Protein name & Gene name & Liquid & Frozen \\
\hline $\begin{array}{l}\text { Ubiquitin-like modifier-activating } \\
\text { enzyme } 1\end{array}$ & UBA1 & & $\uparrow$ \\
\hline Polyubiquitin & $U B B$ & & $\uparrow$ \\
\hline Cullin-3 & CUL3 & & $\uparrow$ \\
\hline Kelch-like protein 10 & KLHL10 & & $\uparrow$ \\
\hline Tripeptidyl-peptidase 2 & TPP2 & & $\uparrow$ \\
\hline $\begin{array}{l}26 \mathrm{~S} \text { proteasome non-ATPase regulatory } \\
\text { subunit } 2\end{array}$ & PSMD2 & & $\uparrow$ \\
\hline Proteasome subunit alpha type, 2 & PSMA2 & $\uparrow$ & \\
\hline Proteasome subunit alpha type-7-like & PSMA8 & $\uparrow$ & \\
\hline $\begin{array}{l}\text { Transitional endoplasmic reticulum } \\
\text { ATPase }\end{array}$ & $V C P$ & $\uparrow$ & $\uparrow$ \\
\hline
\end{tabular}

reorganisation and degradation of proteins occurring during spermatogenesis (Tipler et al. 1997). However, high levels of proteasomal activity have since been found in mature spermatozoa and found to regulate later events such as capacitation, the acrosome reaction and zona pellucida penetration (Arcelay et al. 2008, Kong et al. 2009, Yi et al. 2010, Sanchez et al. 2011, Zimmerman et al. 2011). Similar to the CTT complex, in spermatozoa, the 26 proteasome shows a unique sperm surface localisation (Redgrove et al. 2011, Byrne et al. 2012) rather than a traditional intracellular localisation. Proteasomal proteins have been reported in seminal plasma but scrotal insulation to arrest spermatogenesis resulted in their loss from ram seminal plasma suggesting they were of sperm origin (Soleilhavoup et al. 2014). Three proteins of the $26 \mathrm{~s}$ proteasome (PSMD2, PSMA2, PSMA8) were higher abundant in spermatozoa which showed greater resistance to in vitro preservation (liquid or frozen storage). While these showed a consistent trend within and between the proteomes the large multiprotein 26s complex consists of more than 66 proteins (Bedford et al. 2010) and just under half of these (32 proteins) have been identified in ram seminal plasma (Soleilhavoup et al. 2014). As only three of these were correlated with preservation ability, this represents a relatively small proportion of the complex as a whole. However, a larger number of proteins which provide upstream or downstream support to the 26 s proteasome were also found to be positively correlated with good preservation ability (Table 5). This includes enzymes that mediate the ubiquitin pathway (UBA1, CUL3, KLHL10), ubiquitin itself $(\mathrm{UBB})$, proteins involved in the transport of ubiquitinated proteins to the $26 \mathrm{~s}$ proteasome (VCP) and a peptidase which acts downstream of the $26 \mathrm{~s}$ proteasome (TPP2). The tagging of spermatozoa with ubiquitin is thought to mark the cell as defective and target it for degradation (Sutovsky 2003). Subsequent assessment of sperm ubiquitin levels and sperm function has revealed a more complicated relationship. Increased sperm ubiquitin has been inversely correlated with sperm function in bull (Zhang et al. 2018) and human (Sutovsky et al. 2004) spermatozoa, but ubiquitin levels were high in some human sperm samples with good clinical semen parameters. Ubiquitination has also been positively correlated to normal morphology in human semen (Muratori et al. 2005) and shown to be positively correlated to sperm survival following freeze-thawing in the boar (Purdy 2008). Because the proteasome is a large multi-protein complex, it is unlikely that the positive correlation of UPS proteins in seminal plasma to good sperm preservation ability is due to these proteins functioning in the extracellular medium and having a direct effect on spermatozoa at ejaculation or during in vitro storage. Similar to the subunits identified in the CCT complex, it is expected that the increased abundance of proteins from the UPS pathway in seminal plasma is a diagnostic marker of improved sperm quality due to differences in sperm production and turnover in the testis or epididymis. For example, stressors associated with freezing and thawing such as temperature or osmotic changes could damage sperm proteins, and increased ubiquitination may be indicative of a highly functioning UPS system that is degrading damaged proteins that are detrimental to sperm survival.

\section{Metabolism-related proteins correlated with ram sperm function in vitro}

The majority of metabolic enzymes identified in ram seminal plasma were positively correlated with preservation success (Fig. 2 and Table 6). The maintenance of motility during liquid preservation was particularly correlated with enzymes belonging to the glycolysis pathway that are of sperm origin and located in the cytoplasm (e.g. GPI, TPI, GAPDHS, LHDC, FBPI, ENO1). It is unknown how they are released into the extracellular fluid, but the release of cytoplasmic droplets with remnant cytosol into the luminal fluid is a probable route. The higher concentration of glycolytic enzymes in seminal plasma of sperm samples that show high motility in vitro may be related to an increased abundance of glycolytic machinery in the spermatozoon or may represent higher sperm production. Liquid storage at reduced temperatures $\left(15^{\circ} \mathrm{C}, 24 \mathrm{~h}\right)$ provides some suppression of sperm metabolism compared to physiological temperatures, but the maintenance of energy metabolism following storage is still the most important criteria for successful preservation. As glucose is a source of energy for spermatozoa, higher efficiency energy metabolism would support sperm mobility during preservation. However, metabolic enzymes show a more complicated correlation with fertility than simply more metabolic enzymes equals better sperm function. For example, the amount of enolase (ENO1) in bull spermatozoa was previously reported as a positive marker of bull sperm fertility (Park et al. 2012) and its abundance in seminal plasma is positively associated 
Table 6 Metabolism-related proteins that are statistically more abundant in ram sperm samples shower higher $(\uparrow)$ or lower $(\downarrow)$ motility after liquid (Soleilhavoup et al. 2014) or frozen storage (Rickard et al. 2015).

\begin{tabular}{|c|c|c|c|}
\hline Protein name & Gene name & Liquid & Frozen \\
\hline Neutral alpha-glucosidase $A B$ & GANAB & & $\downarrow$ \\
\hline ATP-citrate synthase & $A C L Y$ & & $\uparrow$ \\
\hline Acylamino-acid-releasing enzyme & APEH & & $\uparrow$ \\
\hline $\begin{array}{l}\text { Betaine-homocysteine } \\
\text { S-methyltransferase } 1\end{array}$ & BHMT & & $\uparrow$ \\
\hline Galactokinase & GALK1 & & $\uparrow$ \\
\hline Alpha mannosidase $2 \mathrm{C} 1$ & MAN2C1 & & $\uparrow$ \\
\hline Sorbitol dehydrogenase & SORD & & $\uparrow$ \\
\hline Fructose-1,6-bisphosphatase 1 & FBP1 & $\uparrow$ & \\
\hline Glucose-6-phosphate isomerase & $G P I$ & $\uparrow$ & \\
\hline Inositol monophosphatase 1 & IMPA1 & $\uparrow$ & \\
\hline I-Lactate dehydrogenase $\mathrm{C}$ chain & $\angle D H C$ & $\uparrow$ & \\
\hline $5^{\prime}$-Nucleotidase & NT5E & $\uparrow$ & \\
\hline Triosephosphate isomerase & TPI1 & $\uparrow$ & \\
\hline Alpha-enolase & ENO1 & $\uparrow$ & $\downarrow$ \\
\hline $\begin{array}{l}\text { Glyceraldehyde-3-phosphate } \\
\text { dehydrogenase, testis-specific }\end{array}$ & GAPDHS & $\uparrow$ & $\downarrow$ \\
\hline
\end{tabular}

with ram sperm preservation during liquid storage, but it is negatively correlated with ram sperm freezing success (Table 6). In the boar, the amount of triosephosphate isomerase (TPI) was negatively correlated with sperm membrane integrity, morphology and motility (Vilagran et al. 2016), the ability of boar spermatozoa to survive cryopreservation (Vilagran et al. 2013) and litter size following artificial insemination (Kwon et al. 2015). Such differences could be species related or due to the measurement of TPI in spermatozoa compared to seminal plasma. The source of the glycolytic enzymes and the mechanism of release into the luminal fluid are also likely to have a significant effect on their correlation to sperm function. In addition to the possibility that these cytosolic glycolytic enzymes are originating from cytoplasmic droplets, it is also possible that they are released from damaged spermatozoa or are not of sperm origin at all. Extracellular vesicles are released along the male reproductive tract from the epithelium of the epididymis or accessory sex glands into the extracellular fluid (Gatti et al. 2005, Aalberts et al. 2014). These small membranous structures are highly enriched in metabolic enzymes (Choi et al. 2015, Yang et al. 2017). Interestingly, since these metabolic complexes are embedded in a membrane, they are functional in the luminal environment and can even produce extracellular ATP (Ronquist et al. 2013a,b). However, when these enzymes are not present in membraneembedded structures and are free soluble proteins in seminal plasma, membrane lysis either in cells or in extracellular structures has occurred. Recently, we isolated extracellular vesicles from ram seminal plasma using density gradient centrifugation and quantitatively compared protein abundance between vesicles and the whole seminal plasma. Many metabolic enzymes showed no quantitative differences (e.g. ENO1, GPI,
LHDC, FBPI) but TPI was 20.4-fold more enriched in the extracellular vesicle prep when compared to whole seminal plasma indicating that this protein does reside in membrane-embedded cytosolic structures in ram seminal plasma and that membrane lysis was minimal (Leahy et al. unpublished data).

\section{Implications and future direction}

Reproductive biologists have long sought to identify specific factors in seminal plasma that are highly correlated with sperm form and function. These proteins could be used as diagnostic predictors of sperm function and fertility or isolated and applied in vitro to prevent sperm damage associated with the application of artificial reproductive technologies. Proteomic assessment of the spermatozoon and its surroundings has provided considerable advances towards these goals and allowed for greater understanding of the physiological function of spermatozoa.

Proteomic characterisation of ram seminal plasma identified over 700 proteins (Soleilhavoup et al. 2014) with the most abundant seminal proteins being secreted from the accessory sex glands (e.g. BSP, BDH2). However, scrotal insulation to arrest spermatogenesis also highlighted many seminal proteins of lower abundance which originate from spermatozoa, most notably proteins involved in large cellular complexes such as the CCT complex, the 26 s proteasome and metabolism enzymes. Comparative proteomic analysis showed that these sperm-associated protein complexes were predominantly associated with high sperm preservation ability. Proteins of the CCT complex appear to be particularly robust markers of preservation ability as all eight proteins in this complex were positively associated with high motility following liquid or frozen storage.

Despite decades of research showing whole seminal plasma, and its abundant secretory components (e.g. BSPs), are beneficial to ram sperm function in vitro and in vivo, relatively few classical seminal plasma proteins (e.g. secreted from the accessory sex glands) were positively associated with sperm preservation in vitro. Such a result highlights the limitations of comparing proteomic and molecular biology studies. The correlation of sperm function to protein abundance requires simplified groupings such as high or low motility or preservation ability and high or low protein abundance. Such discrete grouping can lead to distorted characterisation of protein action as being positive or negative for sperm function. Such a designation is oversimplified as protein effect is highly dependent on environmental conditions. For example, proteins that may be positively correlated to success following natural mating may not be beneficial under extended sperm storage conditions. In addition, many proteins would not be expected to show a linear physiological relationship with sperm function but a more complex 
quadratic association where too much, or too little, of the protein negatively influence sperm function (e.g. immunoglobulins). Assessment of seminal plasma alone also sheds no real light on the amount and nature of seminal proteins that have bound the sperm membrane. It is this interaction that is expected to have the greatest influence on sperm transport and sperm membrane stabilisation in vitro and in vivo. Finally, recent seminal plasma proteomes, such as that of the bull (Viana et al. 2018), have identified 1000+ proteins, and it is expected that a significant proportion of ram seminal plasma proteins remain to be identified and characterised.

While the application of quantitative comparative proteomics is yet to fully explain why the addition of seminal plasma is beneficial to the function of processed ram spermatozoa, it has provided great insight into the function of seminal plasma and identified key proteins that require further investigation. Of note is the functional role of the introduction of EDIL3 to the sperm membrane at ejaculation and the potential in vitro application of the decapacitation factor caltrin (PYY2) or heat shock proteins (e.g. HSP90AA1) as protective factors to prevent handling-induced ram sperm damage.

\section{Declaration of interest}

The authors declare that there is no conflict of interest that could be perceived as prejudicing the impartiality of this review.

\section{Funding}

T Leahy, J P Rickard, N Bernecic and S P de Graaf are supported by funding from Australian Wool Innovation and the NSW Stud Merino Breeders Association Trust.

\section{References}

Aalberts M, Stout TA \& Stoorvogel W 2014 Prostasomes: extracellular vesicles from the prostate. Reproduction 147 R1-R14. (https://doi. org/10.1530/REP-13-0358)

Agarwal A, Ayaz A, Samanta L, Sharma R, Assidi M, Abuzenadah AM \& Sabanegh E 2015 Comparative proteomic network signatures in seminal plasma of infertile men as a function of reactive oxygen species. Clinical Proteomics 12 23. (https://doi.org/10.1186/s12014-015-9094-5)

Arcelay E, Salicioni AM, Wertheimer E \& Visconti PE 2008 Identification of proteins undergoing tyrosine phosphorylation during mouse sperm capacitation. International Journal of Developmental Biology 52 463-472. (https://doi.org/10.1387/ijdb.072555ea)

Bailey JL, Bilodeau JF \& Cormier N 2000 Semen cryopreservation in domestic animals: a damaging and capacitating phenomenon. Journal of Andrology 21 1-7. (https://doi.org/10.1002/j.1939-4640.2000. tb03268.x)

Baker MA 2011 The 'omics revolution and our understanding of sperm cell biology.' Asian Journal of Andrology 13 6-10. (https://doi.org/10.1038/ aja.2010.62)

Baker MA, Hetherington L, Reeves GM \& Aitken RJ 2008 The mouse sperm proteome characterized via IPG strip prefractionation and LC-MS/ MS identification. Proteomics 8 1720-1730. (https://doi.org/10.1002/ pmic.200701020)

Barrios B, Perez-Pe R, Gallego M, Tato A, Osada J, Muino-Blanco T \& Cebrian-Perez JA 2000 Seminal plasma proteins revert the cold- shock damage on ram sperm membrane. Biology of Reproduction 63 1531-1537. (https://doi.org/10.1095/biolreprod63.5.1531)

Bedford JM 2015 The functions - or not - of seminal plasma? Biology of Reproduction 92 18. (https://doi.org/10.1095/biolreprod.114.126045)

Bedford L, Paine S, Sheppard PW, Mayer RJ \& Roelofs J 2010 Assembly, structure and function of the $26 \mathrm{~S}$ proteasome. Trends in Cell Biology 20 391-401. (https://doi.org/10.1016/j.tcb.2010.03.007)

Belleannee C, Belghazi M, Labas V, Teixeira-Gomes AP, Gatti JL, Dacheux JL \& Dacheux F 2011 Purification and identification of sperm surface proteins and changes during epididymal maturation. Proteomics 11 1952-1964. (https://doi.org/10.1002/pmic.201000662)

Bergeron A, Villemure M, Lazure C \& Manjunath P 2005 Isolation and characterization of the major proteins of ram seminal plasma. Molecular Reproduction and Development 71 461-470. (https://doi.org/10.1002/ mrd.20310)

Bier PJ, Hall CE, Duncan JR \& Winter AJ 1977 Measurement of immunoglobulins in reproductive tract fluids of bulls. Veterinary Microbiology 2 1-11. (https://doi.org/10.1016/0378-1135(77)90027-X)

Britto CJ \& Cohn L 2015 Bactericidal/permeability-increasing protein foldcontaining family member $\mathrm{A} 1$ in airway host protection and respiratory disease. American Journal of Respiratory Cell and Molecular Biology 52 525-534. (https://doi.org/10.1165/rcmb.2014-0297RT)

Bromfield EG, Mclaughlin EA, Aitken RJ \& Nixon B 2016 Heat shock Protein member A2 forms a stable complex with angiotensin converting enzyme and protein disulfide isomerase A6 in human spermatozoa. Molecular Human Reproduction 22 93-109. (https://doi.org/10.1093/molehr/gav073)

Byrne K, Leahy T, Mcculloch R, Colgrave ML \& Holland MK 2012 Comprehensive mapping of the bull sperm surface proteome. Proteomics 12 3559-3579. (https://doi.org/10.1002/pmic.201200133)

Cardozo JA, Fernandez-Juan M, Cebrian-Perez JA \& Muino-Blanco T 2008 Identification of RSVP14 and RSVP20 components by two-dimensional electrophoresis and western-blotting. Reproduction in Domestic Animals 43 15-21. (https://doi.org/10.1111/j.1439-0531.2006.00845.x)

Casas I, Sancho S, Ballester J, Briz M, Pinart E, Bussalleu E, Yeste M, Fàbrega A, Rodríguez-Gil JE \& Bonet S 2010The HSP90AA1 sperm content and the prediction of the boar ejaculate freezability. Theriogenology $\mathbf{7 4}$ 940-950. (https://doi.org/10.1016/j.theriogenology.2010.04.021)

Chang MC 1957 A detrimental effect of seminal plasma on the fertilizing capacity of sperm. Nature 179 258-259. (https://doi. org/10.1038/179258a0)

Chang C, Hu M, Zhu Z, Lo LJ, Chen J \& Peng J 2011 Liver-enriched gene $1 \mathrm{a}$ and $1 \mathrm{~b}$ encode novel secretory proteins essential for normal liver development in zebrafish. PLOS ONE 6 e22910. (https://doi.org/10.1371/ journal.pone.0022910)

Chen LY, Lin YH, Lai ML \& Chen YH 1998 Developmental profile of a caltrinlike protease inhibitor, P12, in mouse seminal vesicle and characterization of its binding sites on sperm surface. Biology of Reproduction 59 1498-1505. (https://doi.org/10.1095/biolreprod59.6.1498)

Choi EY, Chavakis E, Czabanka MA, Langer HF, Fraemohs L, Economopoulou M, Kundu RK, Orlandi A, Zheng YY, Prieto DA et al. 2008 Del-1, an endogenous leukocyte-endothelial adhesion inhibitor, limits inflammatory cell recruitment. Science 322 1101-1104. (https:// doi.org/10.1126/science.1165218)

Choi DS, Kim DK, Kim YK \& Gho YS 2015 Proteomics of extracellular vesicles: exosomes and ectosomes. Mass Spectrometry Reviews 34 474-490. (https://doi.org/10.1002/mas.21420)

Coronel CE, Winnica DE, Novella ML \& Lardy HA 1992 Purification, structure, and characterization of caltrin proteins from seminal vesicle of the rat and mouse. Journal of Biological Chemistry 267 20909-20915.

Davies KJA 2016 Adaptive homeostasis. Molecular Aspects of Medicine 49 1-7. (https://doi.org/10.1016/j.mam.2016.04.007)

Davis RO, Overstreet JW, Asch RH, Ord T \& Silber SJ 1991 Movement characteristics of human epididymal sperm used for fertilization of human oocytes in vitro. Fertility and Sterility 56 1128-1135. (https://doi. org/10.1016/S0015-0282(16)54728-1)

de Graaf SP, Evans G, Gillan L, Guerra MMP, Maxwell WMC \& O'Brien JK 2007 The influence of antioxidant, cholesterol and seminal plasma on the in vitro quality of sorted and non-sorted ram spermatozoa. Theriogenology 67 217-227. (https://doi.org/10.1016/j. theriogenology.2006.07.008)

Dematteis A, Miranda SD, Novella ML, Maldonado C, Ponce RH, Maldera JA, Cuasnicu PS \& Coronel CE 2008 Rat caltrin protein modulates the acrosomal exocytosis during sperm capacitation. 
Biology of Reproduction 79 493-500. (https://doi.org/10.1095/ biolreprod.107.067538)

Desnoyers L \& Manjunath P 1992 Major proteins of bovine seminal plasma exhibit novel interactions with phospholipid. Journal of Biological Chemistry 267 10149-10155.

Dondero F, Radicioni A, Gandini L \& Lenzi A 1984 Immunoglobulins in human seminal plasma. Andrologia 16 228-236. (https://doi. org/10.1111/j.1439-0272.1984.tb00271.x)

Dott HM, Harrison RA \& Foster GC 1979 The maintenance of motility and the surface properties of epididymal spermatozoa from bull, rabbit, and ram in homologous seminal and epididymal plasma. Journal of Reproduction and Fertility 55 113-124. (https://doi.org/10.1530/ jrf.0.0550113)

Druart X \& de Graaf SP 2018 Seminal plasma proteomes and sperm fertility. Animal Reproduction Science 194 33-40. (https://doi.org/10.1016/j. anireprosci.2018.04.061)

Druart X, Rickard JP, Mactier S, Kohnke PL, Kershaw-Young CM, Bathgate R, Gibb Z, Crossett B, Tsikis G, Labas V et al. 2013 Proteomic characterization and cross species comparison of mammalian seminal plasma. Journal of Proteomics 91 13-22. (https://doi.org/10.1016/j. jprot.2013.05.029)

Dun MD, Smith ND, Baker MA, Lin M, Aitken RJ \& Nixon B 2011 The chaperonin containing TCP1 complex (CCT/TRiC) is involved in mediating sperm-oocyte interaction. Journal of Biological Chemistry $\mathbf{2 8 6}$ 36875-36887. (https://doi.org/10.1074/jbc.M110.188888)

El-Hajj Ghaoui R, Gillan L, Thomson PC, Evans G \& Maxwell WMC 2007 a Effect of seminal plasma fractions from entire and vasectomized rams on the motility characteristics, membrane status, and in vitro fertility of ram spermatozoa. Journal of Andrology 28 109-122.

El-Hajj Ghaoui R, Thomson PC, Leahy T, Evans G \& Maxwell WMC 2007b Autologous whole ram seminal plasma and its vesicle-free fraction improve motility characteristics and membrane status but not in vivo fertility of frozen-thawed ram spermatozoa. Reproduction in Domestic Animals 42 541-549. (https://doi.org/10.1111/j.1439-0531.2006.00819.x)

Garcia-Lopez N, Ollero M, Cebrian-Perez JA \& Muino-Blanco T 1996 Reversion of thermic-shock effect on ram spermatozoa by adsorption of seminal plasma proteins revealed by partition in aqueous two-phase systems. Journal of Chromatography: B, Biomedical Applications $\mathbf{6 8 0}$ 137-143. (https://doi.org/10.1016/0378-4347(95)00394-0)

Gatti JL, Métayer S, Belghazi M, Dacheux F \& Dacheux JL 2005 Identification, proteomic profiling, and origin of ram epididymal fluid exosome-like vesicles. Biology of Reproduction 72 1452-1465. (https:// doi.org/10.1095/biolreprod.104.036426)

González-Cadavid V, Martins JA, Moreno FB, Andrade TS, Santos AC, Monteiro-Moreira AC, Moreira RA \& Moura AA 2014 Seminal plasma proteins of adult boars and correlations with sperm parameters. Theriogenology 82 697-707. (https://doi.org/10.1016/j. theriogenology.2014.05.024)

Graham JK 1994 Effect of seminal plasma on the motility of epididymal and ejaculated spermatozoa of the ram and bull during the cryopreservation process. Theriogenology 41 1151-1162. (https://doi.org/10.1016/S0093691X(05)80037-8)

Grasso EJ \& Coronel CE 2017 Structure and function of Caltrin (calcium transport inhibitor) proteins. Biochemistry Insights $\mathbf{1 0}$ 1178626417745822. (https://doi.org/10.1177/1178626417745822)

Gwathmey TM, Ignotz GG \& Suarez SS 2003 PDC-109 (BSP-A1/A2) promotes bull sperm binding to oviductal epithelium in vitro and may be involved in forming the oviductal sperm reservoir. Biology of Reproduction 69 809-815. (https://doi.org/10.1095/biolreprod.102.010827)

Gwathmey TM, Ignotz GG, Mueller JL, Manjunath P \& Suarez SS 2006 Bovine seminal plasma proteins PDC-109, BSP-A3, and BSP-30-kDa share functional roles in storing sperm in the oviduct. Biology of Reproduction 75 501-507. (https://doi.org/10.1095/biolreprod.106.053306)

Hale LP, Price DT, Sanchez LM, Demark-Wahnefried W \& Madden JF 2001 Zinc $\alpha$-2-glycoprotein is expressed by malignant prostatic epithelium and may serve as a potential serum marker for prostate cancer. Clinical Cancer Research 7 846-853.

Hu M, Bai Y, Zhang C, Liu F, Cui Z, Chen J \& Peng J 2016 Liver-enriched gene 1 , a glycosylated secretory protein, binds to FGFR and mediates an anti-stress pathway to protect liver development in zebrafish. PLoS Genetics 12 e1005881. (https://doi.org/10.1371/journal.pgen.1005881)
Johansen FE \& Kaetzel CS 2011 Regulation of the polymeric immunoglobulin receptor and IgA transport: new advances in environmental factors that stimulate plgR expression and its role in mucosal immunity. Mucosal Immunology 4 598-602. (https://doi.org/10.1038/mi.2011.37)

Kaetzel CS 2005 The polymeric immunoglobulin receptor: bridging innate and adaptive immune responses at mucosal surfaces. Immunological Reviews 206 83-99. (https://doi.org/10.1111/j.01052896.2005.00278.x)

Kawano N, Araki N, Yoshida K, Hibino T, Ohnami N, Makino M, Kanai S, Hasuwa H, Yoshida M, Miyado K et al. 2014 Seminal vesicle protein SVS2 is required for sperm survival in the uterus. PNAS 111 4145-4150. (https://doi.org/10.1073/pnas.1320715111)

Kelly VC, Kuy S, Palmer DJ, Xu ZZ, Davis SR \& Cooper GJ 2006 Characterization of bovine seminal plasma by proteomics. Proteomics $\mathbf{6}$ 5826-5833. (https://doi.org/10.1002/pmic.200500830)

Kong M, Diaz ES \& Morales P 2009 Participation of the human sperm proteasome in the capacitation process and its regulation by protein kinase A and tyrosine kinase. Biology of Reproduction 80 1026-1035. (https://doi.org/10.1095/biolreprod.108.073924)

Kwon W-S, Rahman MS, Lee J-S, Yoon S-J, Park Y-J \& Pang M-G 2015 Discovery of predictive biomarkers for litter size in boar spermatozoa. Molecular and Cellular Proteomics 14 1230-1240. (doi:10.1074/mcp. M114.045369)

Lane ME, Therien I, Moreau R \& Manjunath P 1999 Heparin and high density lipoprotein mediate bovine sperm capacitation by different mechanisms. Biology of Reproduction 60 169-175. (https://doi. org/10.1095/biolreprod60.1.169)

Leahy T \& de Graaf SP 2012 Seminal plasma and its effect on ruminant spermatozoa during processing. Reproduction in Domestic Animals 47 207-213. (https://doi.org/10.1111/j.1439-0531.2012.02077.x)

Leahy T \& Gadella BM 2011 Sperm surface changes and physiological consequences induced by sperm handling and storage. Reproduction 142 759-778. (https://doi.org/10.1530/REP-11-0310)

Leahy T, Marti JI, Evans G \& Maxwell WMC 2009 Seminal plasma proteins protect flow-sorted ram spermatozoa from freeze-thaw damage. Reproduction, Fertility, and Development 21 571-578. (https://doi. org/10.1071/RD08238)

Leahy T, Celi P, Bathgate R, Evans G, Maxwell WMC \& Marti JI 2010a Flow-sorted ram spermatozoa are highly susceptible to hydrogen peroxide damage but are protected by seminal plasma and catalase. Reproduction, Fertility, and Development 22 1131-1140. (https://doi. org/10.1071/RD09286)

Leahy T, Evans G, Maxwell WMC \& Marti JI 2010b Seminal plasma proteins do not consistently improve fertility after cervical insemination of ewes with non-sorted or sex-sorted frozen-thawed ram spermatozoa. Reproduction, Fertility, and Development 22 606-612. (https://doi. org/10.1071/RD09207)

Leahy T, Marti JI, Evans G \& Maxwell WMC 2010c Seasonal variation in the protective effect of seminal plasma on frozen-thawed ram spermatozoa. Animal Reproduction Science 119 147-153. (https://doi.org/10.1016/j. anireprosci.2009.12.010)

Lewis RV, Agustin JS, Kruggel W \& Lardy HA 1985 The structure of caltrin, the calcium-transport inhibitor of bovine seminal plasma. PNAS 82 6490-6491. (https://doi.org/10.1073/pnas.82.19.6490)

Lin TY, Chou CF, Chung HY, Chiang CY, Li CH, Wu JL, Lin HJ, Pai TW, Hu CH \& Tzou WS 2014 Hypoxia-inducible factor 2 alpha is essential for hepatic outgrowth and functions via the regulation of leg1 transcription in the zebrafish embryo. PLOS ONE 9 e101980. (https://doi.org/10.1371/ journal.pone.0101980)

Lloyd RE, Elliott RMA, Fazeli A, Watson PF \& Holt WV 2009 Effects of oviductal proteins, including heat shock $70 \mathrm{kDa}$ protein 8 , on survival of ram spermatozoa over $48 \mathrm{~h}$ in vitro. Reproduction, Fertility and Development 21 408-418. (https://doi.org/10.1071/RD08204)

López-Pérez A \& Pérez-Clariget R 2012 Ram seminal plasma improves pregnancy rates in ewes cervically inseminated with ram semen stored at $5^{\circ} \mathrm{C}$ for 24 hours. Theriogenology 77 395-399. (https://doi.org/10.1016/j. theriogenology.2011.08.013)

Manjunath P, Bergeron A, Lefebvre J \& Fan J 2007 Seminal plasma proteins: functions and interaction with protective agents during semen preservation. Society of Reproduction and Fertility Supplement $\mathbf{6 5}$ 217-228. 
Manjunath P, Lusignan M \& Bergeron A 2008 Sperm Protection by Extender Components. Budapest, Hungary: Association for Applied Animal Andrology.

Marti E, Mara L, Marti JI, Muino-Blanco T \& Cebrian-Perez JA 2007 Seasonal variations in antioxidant enzyme activity in ram seminal plasma. Theriogenology 67 1446-1454. (https://doi.org/10.1016/j. theriogenology.2007.03.002)

Maxwell WM, Evans G, Mortimer ST, Gillan L, Gellatly ES \& Mcphie CA 1999a Normal fertility in ewes after cervical insemination with frozenthawed spermatozoa supplemented with seminal plasma. Reproduction, Fertility, and Development 11 123-126. (https://doi.org/10.1071/ RD99046)

Maxwell WMC, Evans G, Mortimer ST, Gillan L, Gellatly ES \& Mcphie CA $1999 b$ Normal fertility in ewes after cervical insemination with frozenthawed spermatozoa supplemented with seminal plasma. Reproduction, Fertility, and Development 11 123-126. (https://doi.org/10.1071/ RD99046)

Maxwell WMC, de Graaf SP, El-Hajj Ghaoui R \& Evans G 2007 Seminal plasma effects on sperm handling and female fertility. In Reproduction in Domestic Ruminants VI. Eds JI Juengel, JF Murray \& MF Smith. Nottingham, UK: Nottingham University Press.

Meslin C, Laurin M, Callebaut I, Druart X \& Monget P 2015 Evolution of species-specific major seminal fluid proteins in placental mammals by gene death and positive selection. Contributions to Zoology 84 217-235.

Morrier A, Castonguay F \& Bailey JL 2003 Conservation of fresh ram spermatozoa at 5 degrees $C$ in the presence of seminal plasma. Canadian Journal of Animal Science 83 221-227. (https://doi.org/10.4141/A02060)

Moura AA, Koc H, Chapman DA \& Killian GJ 2006 Identification of proteins in the accessory sex gland fluid associated with fertility indexes of dairy bulls: a proteomic approach. Journal of Andrology 27 201-211. (https://doi.org/10.2164/jandrol.05089)

Muino-Blanco T, Perez-Pe R \& Cebrian-Perez JA 2008 Seminal plasma proteins and sperm resistance to stress. Reproduction in Domestic Animals 43 18-31. (https://doi.org/10.1111/j.1439-0531.2008.01228.x)

Muratori M, Marchiani S, Forti G \& Baldi E 2005 Sperm ubiquitination positively correlates to normal morphology in human semen. Human Reproduction 20 1035-1043. (https://doi.org/10.1093/humrep/deh678)

Nixon B, Dun MD \& Aitken RJ 2017 Proteomic analysis of human spermatozoa. In Immune Infertility: Impact of Immune Reactions on Human Fertility. Eds WKH Krause \& RK Naz. Cham: Springer International Publishing.

Novak S, Smith TA, Paradis F, Burwash L, Dyck MK, Foxcroft GR \& Dixon WT 2010 Biomarkers of in vivo fertility in sperm and seminal plasma of fertile stallions. Theriogenology 74 956-967. (https://doi. org/10.1016/j.theriogenology.2010.04.025)

Ollero M, Cebrian-Perez JA \& Muino-Blanco T 1997 Improvement of cryopreserved ram sperm heterogeneity and viability by addition of seminal plasma. Journal of Andrology 18 732-739.

O'Meara CM, Donovan A, Hanrahan JP, Duffy P, Fair S, Evans ACO \& Lonergan P 2007 Resuspending ram spermatozoa in seminal plasma after cryopreservation does not improve pregnancy rate in cervically inseminated ewes. Theriogenology 67 1262-1268. (https://doi. org/10.1016/j.theriogenology.2007.01.012)

Pang SF, Chow PH \& Wong TM 1979 The role of the seminal vesicles, coagulating glands and prostate glands on the fertility and fecundity of mice. Journal of Reproduction and Fertility 56 129-132. (https://doi. org/10.1530/jrf.0.0560129)

Park YJ, Kwon WS, Oh SA \& Pang MG 2012 Fertility-related proteomic profiling bull spermatozoa separated by Percoll. Journal of Proteome Research 11 4162-4168. (https://doi.org/10.1021/pr300248s)

Peitz B 1988 Effects of seminal vesicle fluid components on sperm motility in the house mouse. Journal of Reproduction and Fertility 83 169-176. (https://doi.org/10.1530/jrf.0.0830169)

Perez-Patino C, Barranco I, Parrilla I, Valero ML, Martinez EA, RodriguezMartinez H \& Roca J 2016 Characterization of the porcine seminal plasma proteome comparing ejaculate portions. Journal of Proteomics 142 15-23. (https://doi.org/10.1016/j.jprot.2016.04.026)

Pérez-Patiño C, Parrilla I, Barranco I, Vergara-Barberán M, SimóAlfonso EF, Herrero-Martínez JM, Rodriguez-Martínez H, Martínez EA \& Roca J 2018 New in-depth analytical approach of the porcine seminal plasma proteome reveals potential fertility biomarkers. Journal of Proteome Research 17 1065-1076. (https://doi.org/10.1021/acs. jproteome.7b00728)

Perez-Pe R, Cebrian-Perez JA \& Muino-Blanco T 2001a Semen plasma proteins prevent cold-shock membrane damage to ram spermatozoa. Theriogenology $56 \quad 425-434$. (https://doi.org/10.1016/S0093691X(01)00574-X)

Perez-Pe R, Muino-Blanco T \& Cebrian-Perez JA 2001b Sperm washing method alters the ability of seminal plasma proteins to revert the cold-shock damage on ram sperm membrane. International Journal of Andrology 24 352-359. (https://doi.org/10.1046/j.13652605.2001.00315.x)

Perez-Pe R, Grasa P, Fernandez-Juan M, Peleato ML, Cebrian-Perez JA \& Muino-Blanco T 2002 Seminal plasma proteins reduce protein tyrosine phosphorylation in the plasma membrane of cold-shocked ram spermatozoa. Molecular Reproduction and Development 61 226-233. (https://doi.org/10.1002/mrd.1152)

Peterson LW \& Artis D 2014 Intestinal epithelial cells: regulators of barrier function and immune homeostasis. Nature Reviews: Immunology $\mathbf{1 4}$ 141-153. (https://doi.org/10.1038/nri3608)

Phalipon A \& Corthésy B 2003 Novel functions of the polymeric Ig receptor: well beyond transport of immunoglobulins. Trends in Immunology 24 55-58. (https://doi.org/10.1016/S1471-4906(02)00031-5)

Pini T, Leahy T, Soleilhavoup C, Tsikis G, Labas V, Combes-Soia L, Harichaux G, Rickard JP, Druart X \& de Graaf SP 2016 Proteomic investigation of ram spermatozoa and the proteins conferred by seminal plasma. Journal of Proteome Research 15 3700-3711. (https://doi. org/10.1021/acs.jproteome.6b00530)

Pini T, Farmer K, Druart X, Teixeira-Gomes AP, Tsikis G, Labas V, Leahy T \& de Graaf SP 2018a Binder of sperm proteins protect ram spermatozoa from freeze-thaw damage. Cryobiology 82 78-87. (https:// doi.org/10.1016/j.cryobiol.2018.04.005)

Pini T, Rickard JP, Leahy T, Crossett B, Druart X \& de Graaf SP 2018 b Cryopreservation and egg yolk medium alter the proteome of ram spermatozoa. Journal of Proteomics 181 73-82. (https://doi. org/10.1016/j.jprot.2018.04.001)

Purdy PH 2008 Ubiquitination and its influence in boar sperm physiology and cryopreservation. Theriogenology 70 818-826. (https://doi. org/10.1016/j.theriogenology.2008.05.044)

Qu F, Ying X, Guo W, Guo Q, Chen G, Liu Y \& Ding Z 2007 The role of Zn$\alpha 2$ glycoprotein in sperm motility is mediated by changes in cyclic AMP. Reproduction 134 569-576. (https://doi.org/10.1530/REP-07-0145)

Queen K, Dhabuwala CB \& Pierrepoint CG 1981 The effect of the removal of the various accessory sex glands on the fertility of male rats. Journal of Reproduction and Fertility 62 423-426. (https://doi.org/10.1530/ jrf.0.0620423)

Redgrove KA, Anderson AL, Dun MD, Mclaughlin EA, O'Bryan MK, Aitken RJ \& Nixon B 2011 Involvement of multimeric protein complexes in mediating the capacitation-dependent binding of human spermatozoa to homologous zonae Pellucidae. Developmental Biology 356 460-474. (https://doi.org/10.1016/j.ydbio.2011.05.674)

Rickard JP, Pini T, Soleilhavoup C, Cognié J, Bathgate R, Lynch GW, Evans G, Maxwell WM, Druart X \& de Graaf SP 2014 Seminal plasma aids the survival and cervical transit of epididymal ram spermatozoa. Reproduction 148 469-478. (https://doi.org/10.1530/REP-14-0285)

Rickard JP, Leahy T, Soleilhavoup C, Tsikis G, Labas V, Harichaux G, Lynch GW, Druart X \& de Graaf SP 2015 The identification of proteomic markers of sperm freezing resilience in ram seminal plasma. Journal of Proteomics 126 303-311. (https://doi.org/10.1016/j.jprot.2015.05.017)

Rickard JP, Schmidt RE, Maddison JW, Bathgate R, Lynch GW, Druart X \& de Graaf SP 2016 Variation in seminal plasma alters the ability of ram spermatozoa to survive cryopreservation. Reproduction, Fertility, and Development 28 516-523. (https://doi.org/10.1071/RD14123)

Robertson SA 2007 Seminal fluid signaling in the female reproductive tract: Lessons from rodents and pigs1. Journal of Animal Science 85 E36-E44. (https://doi.org/10.2527/jas.2006-578)

Rodrigues MAM, Souza CEA, Martins JAM, Rego JPA, Oliveira JTA, Domont G, Nogueira FCS \& Moura AA 2013 Seminal plasma proteins and their relationship with sperm motility in Santa Ines rams. Small Ruminant Research 109 94-100. (https://doi.org/10.1016/j. smallrumres.2012.07.032)

Ronquist KG, Ek B, Morrell J, Stavreus-Evers A, Holst BS, Humblot P, Ronquist G \& Larsson A 2013a Prostasomes from four different 
species are able to produce extracellular adenosine triphosphate (ATP). Biochimica et Biophysica Acta 1830 4604-4610. (https://doi. org/10.1016/j.bbagen.2013.05.019)

Ronquist KG, Ek B, Stavreus-Evers A, Larsson A \& Ronquist G 2013b Human prostasomes express glycolytic enzymes with capacity for ATP production. American Journal of Physiology: Endocrinology and Metabolism $304 \quad$ E576-E582. (https://doi.org/10.1152/ ajpendo.00511.2012)

Rupik W, Jasik K, Bembenek J \& Widłak W 2011 The expression patterns of heat shock genes and proteins and their role during vertebrate's development. Comparative Biochemistry and Physiology: Part A, Molecular and Integrative Physiology 159 349-366. (https://doi. org/10.1016/j.cbpa.2011.04.002)

Sanchez R, Deppe M, Schulz M, Bravo P, Villegas J, Morales P \& Risopatron J 2011 Participation of the sperm proteasome during in vitro fertilisation and the acrosome reaction in cattle. Andrologia 43 114-120. (https://doi.org/10.1111/j.1439-0272.2009.01031.x)

Sarkar S, Singh MD, Yadav R, Arunkumar KP \& Pittman G 2011 Heat shock proteins: molecules with assorted functions. Frontiers in Biology $6312-327$.

Slowinska M, Nynca J, Arnold GJ, Frohlich T, Jankowski J, Kozlowski K, Mostek A \& Ciereszko A 2017 Proteomic identification of turkey (Meleagris gallopavo) seminal plasma proteins. Poultry Science $\mathbf{9 6}$ 3422-3435. (https://doi.org/10.3382/ps/pex132)

Soleilhavoup C, Tsikis G, Labas V, Harichaux G, Kohnke PL, Dacheux JL, Guérin Y, Gatti JL, de Graaf SP \& Druart X 2014 Ram seminal plasma proteome and its impact on liquid preservation of spermatozoa. Journal of Proteomics 109 245-260. (https://doi.org/10.1016/j.jprot.2014.07.007)

Somashekar L, Selvaraju S, Parthipan S \& Ravindra JP 2015 Profiling of sperm proteins and association of sperm PDC-109 with bull fertility. Systems Biology in Reproductive Medicine 61 376-387. (https://doi.org/ 10.3109/19396368.2015.1094837)

Souza CEA, Rego JPA, Lobo CH, Oliveira JTA, Nogueira FS, Domont GB, Fioramonte M, Gozzo FC, Moreno FB, Monteiro-Moreira ACO et al. 2012 Proteomic analysis of the reproductive tract fluids from tropicallyadapted Santa Ines rams. Journal of Proteomics $194436-4456$.

Sutovsky P 2003 Ubiquitin-dependent proteolysis in mammalian spermatogenesis, fertilization, and sperm quality control: killing three birds with one stone. Microscopy Research and Technique 61 88-102. (https://doi.org/10.1002/jemt.10319)

Sutovsky P, Hauser R \& Sutovsky M 2004 Increased levels of sperm ubiquitin correlate with semen quality in men from an andrology laboratory clinic population. Human Reproduction 19 628-638. (https:// doi.org/10.1093/humrep/deh131)

Talevi R \& Gualtieri R 2010 Molecules involved in sperm-oviduct adhesion and release. Theriogenology 73 796-801. (https://doi.org/10.1016/j. theriogenology.2009.07.005)

Tipler CP, Hutchon SP, Hendil K, Tanaka K, Fishel S \& Mayer RJ 1997 Purification and characterization of $26 \mathrm{~S}$ proteasomes from human and mouse spermatozoa. Molecular Human Reproduction 3 1053-1060. (https://doi.org/10.1093/molehr/3.12.1053)
Tseng HC, Lee RK-K, Hwu YM, Lu CH, Lin MH \& Li SH 2013 Mechanisms underlying the inhibition of murine sperm capacitation by the seminal protein, SPINKL. Journal of Cellular Biochemistry 114 888-898. (https:// doi.org/10.1002/jcb.24428)

Viana AGA, Martins AMA, Pontes AH, Fontes W, Castro MS, Ricart CAO, Sousa MV, Kaya A, Topper E, Memili E et al. 2018 Proteomic landscape of seminal plasma associated with dairy bull fertility. Scientific Reports $\mathbf{8}$ 16323. (https://doi.org/10.1038/s41598-018-34152-w)

Vilagran I, Castillo J, Bonet S, Sancho S, Yeste M, Estanyol JM \& Oliva R 2013 Acrosin-binding protein (ACRBP) and triosephosphate isomerase (TPI) are good markers to predict boar sperm freezing capacity. Theriogenology $\mathbf{8 0}$ 443-450. (https://doi.org/10.1016/j. theriogenology.2013.05.006)

Vilagran I, Castillo-Martín M, Prieto-Martínez N, Bonet S \& Yeste M 2016 Triosephosphate isomerase (TPI) and epididymal secretory glutathione peroxidase (GPX5) are markers for boar sperm quality. Animal Reproduction Science 165 22-30. (https://doi.org/10.1016/j. anireprosci.2015.12.001)

Yang C, Guo WB, Zhang WS, Bian J, Yang JK, Zhou QZ, Chen MK, Peng W, Qi T, Wang CY et al. 2017 Comprehensive proteomics analysis of exosomes derived from human seminal plasma. Andrology 5 1007-1015. (https://doi.org/10.1111/andr.12412)

Yi YJ, Manandhar G, Sutovsky M, Jonakova V, Park CS \& Sutovsky P 2010 Inhibition of 195 proteasomal regulatory complex subunit PSMD8 increases polyspermy during porcine fertilization in vitro. Journal of Reproductive Immunology 84 154-163. (https://doi.org/10.1016/j. jri.2009.11.002)

Zalazar L, Ledesma A, Hozbor F \& Cesari A 2016 Heterologous recombinant protein with decapacitating activity prevents and reverts cryodamage in ram sperm: an emerging biotechnological tool for cryobiology. Animal Reproduction Science 164 31-39. (https://doi. org/10.1016/j.anireprosci.2015.11.007)

Zhang J, Su J, Hu S, Zhang J, Ding R, Guo J, Cao G, Li R, Sun QY \& Li X 2018 Correlation between ubiquitination and defects of bull spermatozoa and removal of defective spermatozoa using anti-ubiquitin antibody-coated magnetized beads. Animal Reproduction Science 192 44-52. (https://doi.org/10.1016/j.anireprosci.2018.01.018)

Zimmerman SW, Manandhar G, Yi YJ, Gupta SK, Sutovsky M, Odhiambo JF, Powell MD, Miller DJ \& Sutovsky P 2011 Sperm proteasomes degrade sperm receptor on the egg zona pellucida during mammalian fertilization. PLOS ONE 6 e17256. (https://doi.org/10.1371/journal.pone.0017256)

Received 12 December 2018

First decision 25 January 2019

Revised manuscript received 4 February 2019

Accepted 7 March 2019 